\title{
The "Essence" of International Human Rights
}

\author{
Pierre Thielbörger*
}

(Received 01 May 2019; accepted 30 May 2019)

\begin{abstract}
While the "essence" of EU fundamental rights has received much attention following the CJEU's Schrems decision, the concept of "essence" remains much less examined in international human rights law. Nonetheless, a concept of "essence" for human rights can also be found in international law. This Article discusses different aspects of the "essence" concept in international human rights law, namely non-derogability, non-restrictability, and minimum core, in three steps. First, the Article looks at civil political rights and socioeconomic rights separately and identifies two different approaches to the concept of essence for each of the two categories: While for civil and political rights the concept of essence is mainly linked to the notions of non-derogability and non-restrictability, for socioeconomic rights, the concept refers mainly to the states' obligation to guarantee an essential level of protection independent of their resource limitations. Second, the Article continues by reading the two approaches together and identifies certain elements of an overarching "essence" concept. Finally, the Article discusses the relationship between the CJEU's "essence" jurisprudence and the related concepts in international law and concludes with two theses: First, international law deserves more attention when reflecting on the EU's concept of essence. It equally employs concepts of "essence" and also informs the development and interpretation of EU law. Second, when engaging with the question of whether the EU law should draw lessons from its international counterpart on the notion of "essence," one must contemplate drawbacks for EU law that the concept has presented for international law.
\end{abstract}

Keywords: Human rights; international law; essence; non-restrictability; non-derogability; minimum core obligations; justifiability; civil and political rights; socioeconomic rights

\section{A. Introduction}

The essence of the jurisprudence following the ruling of the Court of Justice for the European Union (CJEU) in Schrems ${ }^{1}$ has received heightened attention by many legal observers. ${ }^{2}$ In Schrems, the CJEU's Grand Chamber stated, in a case on data protection, that "legislation permitting public authorities to have access to the content of electronic communications on a generalized basis must be regarded as compromising the essence of the fundamental right to respect for private life, as guaranteed in Art. 7 of the Charter," 3 and that

\footnotetext{
${ }^{\star}$ Pierre Thielbörger is a professor of German public law and public international law at Ruhr University Bochum and the Executive Director of the Institute for International Law of Peace and Armed Conflict (IFHV) at said university. Thanks to Marius Fritz, Rouven Diekjobst and Maximilian Bertamini for their help with editing and research.

${ }^{1}$ Case C-362/14, Schrems v. Data Protection Comm'n, 2015 E.C.R. 627.

${ }^{2}$ Tuomas Ojanen, Making the Essence of Fundamental Rights Real: The Court of Justice of the European Union Clarifies the Structure of Fundamental Rights under the Charter, 12 Eur. ConsT. L. REv. 318, 318-29 (2016); Maja Brkan, The Concept of Essence of Fundamental Rights in the EU Legal Order: Peeling the Onion to its Core, 14 Eur. CONST. L. REV. 332, 332-68 (2018).

${ }^{3}$ Schrems, Case C-362/14 at para. 94
} 
[1]ikewise, legislation not providing for any possibility for an individual to pursue legal remedies in order to have access to personal data relating to him, or obtain the rectification or erasure of such data, does not respect the essence of the fundamental right to effective judicial protection, as enshrined in Article 47 of the Charter. ${ }^{4}$

Schrems is remarkable in that it is the first successful application to a concrete case of the general rule stipulated in Article 52(1) of the EU Charter of Fundamental Rights and Freedoms, which states that "[a]ny limitation on the exercise of the rights and freedoms recognized by this Charter must be provided for by law and respect the essence of those rights and freedoms." In the cases of Digital Rights Ireland ${ }^{5}$ and Tele2 Sverige, ${ }^{6}$ the Court had also referred to the "essence" of EU fundamental rights, but did not find a breach thereof.

The idea of an essence ${ }^{7}$ of human or fundamental rights is also well known in many national legal orders. ${ }^{8}$ Article 19(2) of the German Grundgesetz (GG), which is considered a trendsetter with regard to the essence of fundamental rights, ${ }^{9}$ states that "[i]n no case may the essence of a basic right be affected." 10 Several other European constitutions mention the concept of "essence" of basic rights in a similar way; for example, Article 31(3)(2) of the Polish constitution ${ }^{11}$ and Article 53(1)(2)of the Spanish constitution, ${ }^{12}$ just to name two very prominent European examples. ${ }^{13}$ In public international law, ${ }^{14}$ the reference to the concept of essence is more hidden and fragmented (see below on Art. 4 and Art. 5 ICCPR as well as Art. 4 ICESCR and Art. 2 (1) ICESCR). Nonetheless, international law has also developed and employed a concept of "essence" for human rights. To be precise, it has even employed several versions of such a concept.

\footnotetext{
${ }^{4}$ Schrems, Case C-362/14 at para. 95.

${ }^{5}$ Joined Cases 293 \& 594/12, Digital Rights Ireland, Ltd. v. Minister for Commc'n, 2014 E.C.R. 238, paras. 38-40.

${ }^{6}$ Case C-203/15, Tele 2 Sverige, 2015 E.C.R. 572, para. 101.

${ }^{7}$ This Article uses the notion "essence" as this is the terminology in EU law which is the starting point for this Article. The international literature, however, has used terminology for the same or similar concepts, such as "minimum" core, see Katharine Young, The Minimum Core of Economic, Social and Cultural Rights: A Concept in Search of Content, 33 YALE INT'L L.J. 113, 113 (2008); David Bilchitz, Towards a Reasonable Approach to the Minimum Core: Laying the Ground for Future Socio-Economic Rights Jurisprudence, 19 S. AFR. J. HuM. RTs. 1, 1 (2003); or "absolute" core, see Julian Rivers, Proportionality and Variable Intensity of Review, 65 CAMBRIDGE L.J. 174, 181 (2006). How these different terminologies are relating to each other will be developed in the following.

${ }^{8}$ For a good overview, see Gerhard van der Schyff, Cutting the Core of Conflicting Rights: The Question of Inalienable Cores in Comparative Perspective, in Conflicts Between Fundamental Rights 131, 131-47 (Eva Brems ed., 2008).

${ }^{9}$ Jochen von Bernstorf, Kerngehaltsschutz durch den UN-Menschenrechtsausschuss und den EGMR: vom Wert kategorialer Argumentationsformen, 50 DER STAAT 165, 171 (2011); Armin von Bogdandy et al., Reverse Solange-Protecting the Essence of Fundamental Rights Against EU Member States, 49 CoMmon MKT. L. REv. 489, 510 (2012); Brkan, supra note 2, at 340-41.

${ }^{10}$ In the German original, this reads, "In keinem Falle darf ein Grundrecht in seinem Wesensgehalt angetastet werden." German is, of course, the relevant_-authentic_text for interpretation, and "Wesensgehalt" could also be translated in other ways, such as in its "core," "spirit," "very substance," or "fundamental character."

${ }^{11}$ Konstytucja Rzeczypospolitej Polskiej [Constitution] Apr. 2, 1997, art. 31(3)(2) (Pol.). "Ograniczenia te nie mogą naruszać istoty wolności i praw," which means, "These limitations shall not violate the essence of freedoms and rights." "Istoty" can be translated as the "essence."

${ }^{12}$ Constitución Española, B.O.E. n. 311, art. 53(1)(2) Dec. 29, 1978 (Spain). "Sólo por ley, que en todo caso deberá respetar su contenido esencial, podrá regularse el ejercicio de tales derechos y libertades, que se tutelarán de acuerdo con lo previsto en el artículo 161, 1, a)", which means, "Only by law, which in any case must respect its essential content, may the exercise of such rights and freedoms be regulated, which shall be protected in accordance with the provisions of article 161., 1, a)." "Su contenido esencia" describes the rights' "essential content."

${ }^{13}$ Other EU-examples include the constitutions of Hungary, Austria, and Poland. For a good overview, see Brkan, supra note 2, at 341-44. Other non-EU examples are Turkey, Argentina, Namibia, Switzerland, and South Africa. See Brkan, supra note 9 , at 340 .

${ }^{14}$ This Article is concerned with public international law in general, not with the certainly equally important question of "essence" under ECHR law. See Sébastien Van Drooghenbroeck \& Cecilia Rizcallah, The ECHR and the Essence of Fundamental Rights: Searching for Sugar in Hot Milk?, 20 GERMAN L.J. 904 (2019).
} 
This Article first recaps some important differentiating features of the two dominant categories of human rights in international law, namely civil and political rights-so called first generation rights, or civil political rights - and economic, social, and cultural rights - so called second generation rights, or socioeconomic rights. One of the main theses of this Article is that the idea of an "essence" must be understood very differently for each of these sets of rights. For civil political rights, the concept must mainly be linked to notions of non-derogability and non-restrictability. For socioeconomic rights, the concept, while also partly being connected to non-restrictability, is most relevant in terms of guaranteeing an essential level of protection that States have to uphold immediately and independent of potential resource limitations.

In reading these two different approaches in international human rights law together, the Article then identifies certain elements of an overarching "essence" concept within international human rights law. Some of these features relate to the macro level of international human rights law: They identify which human rights are most essential within the existing human rights canon. Other features relate to the micro level of the individual human right: They describe a core part within each right that is sacrosanct from State interference.

In a third and final step, the Article sheds light on the relationship between the CJEU's "essence" jurisprudence and the related concepts in international law. It concludes with two theses. First, when looking for the origins of the EU's "essence" jurisprudence, attention has been wrongly focused exclusively on the Member States' traditions and the jurisprudence of European Court of Human Rights (ECtHR). ${ }^{15}$ Public international law deserves similar attention when understanding the EU's concept of essence, as it equally employs concepts of "essence" and also informs the development and interpretation of EU law. Second, when engaging with the question of whether the European legal order should draw further lessons from its international counterpart on the notion of "essence", one must contemplate considerable drawbacks that the concept has presented for international law. For instance, it risks deepening the divide between civil political rights and socioeconomic rights which has, so far, been less strict in EU law.

\section{B. "Essence" as a Concept for Civil Political and Economic, Social, and Cultural Rights?}

When examining whether and how an "essence" concept was established in international law, the distinction between different categories of human rights becomes crucial. First generation human rights, as expressed in the International Covenant on Civil and Political Rights (ICCPR), and second generation human rights, stemming from the International Covenant on Economic, Social and Cultural Rights (ICESCR), are fundamentally different in several ways. ${ }^{16}$

Civil political rights ensure the individual's potential to participate in civil and political life in State and society. They protect individuals' physical and mental integrity in Articles 6, 7, 9, and 10 ICCPR, ensure individuals' freedom in their personal space, such as the right to privacy, home, family, and correspondence in Article 17 ICCPR, or guarantee the freedom of thought, conscience, and religion in Article 18 ICCPR, as well as opinion and expression in Article 19 ICCPR. Civil political rights also ensure non-discriminatory treatment in Articles 2(1) and 26 ICCPR, guarantee judicial rights in Articles 14 and 15 ICCPR, and protect the right to take part in the political system in Article 25 ICCPR. While States under Article 2(1) ICCPR have the obligation to "respect" and to "ensure" the rights of individuals within the State's territory and subject to its jurisdiction, the

\footnotetext{
${ }^{15}$ See, for instance, Brkan, supra note 2 , at 338, who argues that, when seeking to understand the notion of essence in EU law, national constitutions and the ECHR also have to be taken into account. No reference is made by Brkan to public international law in general.

${ }^{16}$ There is also a third generation of human rights in international law. These rights are group rights, such as the right to self-determination, the right to development, or the right to a clean environment. The analysis omits these from the analysis, as the concept of essence has not been applied to group rights in the past. The third generation will, however, become important for the analysis again in the conclusion, see infra Section F.
} 
traditional focus of State action lies on the first obligation, the so called "negative" duty of States to respect human rights with the second obligation continuously increasing in importance. ${ }^{17}$ The obligations are, in principle, due immediately and independent of the question of the available resources of the State in question, as none of these potential limitations are mentioned in Article 2(1) ICCPR. ${ }^{18}$

This is different for economic, social, and cultural rights. They are concerned with the economic, social, and cultural status of the individual in State and society. This includes rights such as the right to education in Article 13 ICESCR, the right to an adequate standard of living including adequate food, clothing, and housing in Article 11 ICESCR and the right to the highest attainable standard of health in Article 12 ICESCR, but also the right to take part in cultural life in Article 15 ICESCR. Member States hold a trias of legal obligations to "respect, protect and fulfil" socioeconomic rights. To respect means a negative obligation for the State not to interfere with individuals' human rights; to protect means to guard individuals' rights against interference by third parties like private actors; and to fulfil means to develop the full realization of the rights progressively over time. This trias was famously conceptualized by Henry Shue ${ }^{19}$ who argued for a duty to avoid depriving, to protect from deprivation, and to help the deprived. This trias was later also explicitly recognized by the United Nations. ${ }^{20}$ Policy results are generally not owed immediately and resource-independently, but States must work towards their progressive realization with the maximum of their available resources, according to Art. 2 I ICESCR. Allegedly, the focus of States' actions often lies on duties to protect and fulfil ${ }^{21}$ — usually more positive State action is required, such as to build houses or to fund hospitals, than for the realization of civil political rights.

This strict distinction between civil political and socioeconomic rights has often been criticized or called into question. ${ }^{22}$ Especially in the Anglo-American tradition, observers have often stressed the categorical difference between both sets of rights by arguing that socioeconomic rights have an aspirational character and that they should not be seen as justiciable. ${ }^{23}$ In practical terms, the distinction between both sets of rights remains highly relevant. First, the wording of the owed obligations in Article 2 of both Covenants respectively is undeniably very different. Second, the signatory States to both Covenants vary dramatically - in particular, the United States remains outside of the ICESCR regime. ${ }^{24}$ Third, the ICCPR has had an individual complaint procedure

\footnotetext{
${ }^{17}$ Frédéric Mégret, Nature of Obligations, in InTernational Human Rights LaW 97, 98 (Daniel Moeckli et al. eds., 3rd ed. 2018). For a good overview, see also CHristian Tomuschat, Human Rights 146 (2014) (who, however, distances himself from such a limited understanding of civil political rights).

${ }^{18}$ U.N. Human Rights Committee (HRC), General Comment No. 31 [80], The nature of the general legal obligation imposed on States Parties to the Covenant, U.N. Doc. CCPR/C/21/Rev.1/Add.13 (May 26, 2004); CESCR General Comment No. 3, The Nature of States Parties' Obligations (Art. 2, para. 1, of the Covenant), para. 9 U.N. Doc. E/1991/23 (Dec. 14, 1990).

${ }^{19}$ Henry Shue, Basic Rights, Subsistence, Affluence, and US Foreign Policy 52 (2d ed. 1996).

${ }^{20}$ First recognized in U.N. Commission on Human Rights, The Right to Adequate Food as Human Right, U.N. Doc. E/CN.4/ Sub.2/1987/23 (Mar. 7, 1988). The previous notion of a four-partite system of obligation-respect, protect, ensure, and promote-as conceptualized in E/CN.4/Sub.2/1983/25 (1983) was dropped and replaced by the trias of obligation.

${ }^{21}$ Frédéric Mégret, Nature of Obligations, in InTERnATIONAL Human RigHTs LaW 97, 99 (Daniel Moeckli et al. eds, 3d ed. 2018).

${ }^{22}$ Theo van Boven, Categories of Rights, in International Human Rights Law 136, 136-37 (Daniel Moeckli et al. eds., 3d ed. 2018); Christian Tomuschat, Human Rights 26 (2014); Pierre Thielbörger, The Right(s) to Water, The MultiLevel Governance of a Unique Human Right 117-19 (2014). For the U.N. explicitly, out of many documents, see G.A. Res. 60/251 para. 3 (Apr. 3, 2006) ("Reaffirming further that all human rights are universal, indivisible, interrelated, interdependent and mutually reinforcing, and that all human rights must be treated in a fair and equal manner, on the same footing and with the same emphasis.").

${ }^{23}$ Michael J. Dennis and David P. Stewart, Justiciability of Economic, Social, and Cultural Rights: Should There Be an International Complaints Mechanism to Adjudicate the Rights to Food, Water, Housing, and Health?, 98 U.S. J. INT'L L. $462,462-515$ (2004).

${ }^{24}$ For a good-albeit by now outdated - summary of the US position on non-ratification of the ICESCR, see Philip Alston, U.S. Ratification of the Covenant on Economic, Social and Cultural Rights: The Need for an Entirely New Strategy, 84 U.S. J. INT'L L. 365, 367-68 (1990).
} 
before the Human Rights Committee since $1976,{ }^{25}$ while the individual complaint procedure to the ICESCR is new, having being established in 2013, and has issued only sixteen opinions so far. ${ }^{26}$

If one takes from these facts that civil political rights are somewhat more important, or perceived by States as such, civil political rights might be regarded as more "essential" than their socioeconomic counterparts. In this way, the notion of "essence" could relate primarily or even exclusively to civil political rights, whereas socioeconomic rights would be regularly or even categorically considered to be without "essence." As a consequence, we would have to limit our search for essence in international human rights law to civil political rights.

An approach limiting the concept of essence to civil political rights would be, however, unconvincing, as it is unreflective of the global human rights canon as it has evolved over the last four decades. We know that socioeconomic rights and civil political rights are highly interdependent ${ }^{27}$ - often socioeconomic rights are even the precondition for realizing civil political rights. ${ }^{28}$ There is also no indication in the drafting history of both Covenants that one set of rights was seen as superior to the other-it was for more practical reasons and in particular the clash of the ideologies of capitalism and communism that lead to their separation into two Covenants. ${ }^{29}$ Rather than being different in their importance, both sets of human rights are different in their focus on the part of human life they set out to protect and to promote. Both can potentially be essential.

While thus rejecting the thesis that the notion of essence is limited to civil political rights, the concept of "essence" has in the past indeed been understood differently for both sets of human rights, as will be outlined in the following.

\section{The Notion of "Essence" in Civil and Political Rights}

Neither the ICCPR nor any of the other core human rights instruments relating to civil political rights $^{30}$ explicitly mention the term "essence." Nonetheless, there are important rules laid down in Article 4 ICCPR and Article 5 ICCPR that speak indirectly to the notion of the "essence" of civil political rights.

\section{Article 4(1) and Article 4(2) ICCPR}

According to Article 4(1) ICCPR,

[i]n time of public emergency which threatens the life of the nation ... the States Parties ... may take measures derogating from their obligations under the present Covenant to

\footnotetext{
${ }^{25}$ Currently, the ICCPR OP has 116 signatories. See Optional Protocol to the International Covenant on Civil and Political Rights, Mar. 23, 1976, 999 U.N.T.S. 171, https://treaties.un.org/doc/Publication/MTDSG/Volume\%20I/Chapter\%20IV/IV-5.en.pdf.

${ }^{26}(2019)$ https://juris.ohchr.org/en/search/results?Bodies=9\&sortOrder=Date (last visited on July 10, 2019).

${ }^{27}$ World Conference on Human Rights, Vienna Declaration and Programme of Action, para. 5, U.N. Doc. A/CONF.157/23 (June 25, 1993); G.A. Res. 60/1, para. 3 (Apr. 3, 2006).

${ }^{28}$ SHUE, supra note 19 , at $24-27$.

${ }^{29}$ Manfred Nowak, The Need for an Optional Protocol to the International Covenant on Economic, Social and Cultural Rights, 55 Rev. INT'L COMM'N JURISTS 153, 153 (1995), available at https://www.icj.org/wp-content/uploads/2013/08/ICJReview-55-1995-eng.pdf; Kitty Arambulo, Strengthening the Supervision of the International Covenant on Economic, Social and Cultural Rights: Theoretical and Procedural Aspects 16-18 (1999).

${ }^{30}$ These are: The International Convention on the Elimination of All Forms of Racial Discrimination, Mar. 7, 1966, 660 U.N.T.S. 195 [hereinafter ICERD]; Convention on the Elimination of All Forms of Discrimination Against Women, Dec. 18, 1979, 1249 U.N.T.S. 13 [hereinafter CEDAW]; Convention against Torture and Other Cruel, Inhuman or Degrading Treatment or Punishment, Dec. 10, 1984, 1465 U.N.T.S. 85 [hereinafter CAT]; Convention on the Rights of the Child, Nov. 20, 1989, 1577 U.N.T.S. 3 [hereinafter CRC]; International Convention on the Protection of the Rights of All Migrant Workers and Members of Their Families, Dec. 18, 1990, 2220 U.N.T.S. 3 [hereinafter ICMW]; International Convention for the Protection of All Persons from Enforced Disappearance, Dec. 20, 2006, 2716 U.N.T.S. 3 [hereinafter ICPED]; Convention on the Rights of Persons with Disabilities, Dec. 13 2006, 2515 U.N.T.S. 3 [hereinafter ICRPD].
} 
the extent strictly required by the exigencies of the situation, provided that such measures are not inconsistent with their other obligations under international law and do not involve discrimination solely on the ground of race, color, sex, language, religion or social origin.

The American Convention on Human Rights (ACHR) knows a similar rule in its Article 27 "suspension of guarantees," as does the European Convention on Human Rights (ECHR) in Article 15 "derogation in time of emergency." Article 4(2) ICCPR goes on to specify that "[n]o derogation from articles 6, 7, 8 (paragraphs 1 and 2), 11, 15, 16 and $18^{31}$ may be made under this provision." Similarly, the ACHR excludes the possibility of suspension for certain listed rights in its Article 27(2) ${ }^{32}$ as does the ECHR in its Article 15(2). ${ }^{33}$ It is debatable whether these lists of non-derogable rights are exhaustive. The Human Rights Committee has expressed its view that the list within Article4(2) ICCPR is not closed, and that other rights could also be considered as non-derogable. ${ }^{34}$ This is partially justified by the Committee with the importance of human rights altogether and partially with a view to the interconnectedness of certain human rights, such as between Article 7 ICCPR - the ban on torture or to cruel, inhuman, or degrading treatment or punishment - which is mentioned in Article 4(2) ICCPR as non-derogable, and Article 10 ICCPR-humane treatment of persons deprived of their liberty-which is not mentioned in Article 4(2) ICCPR. It is furthermore noteworthy that these non-derogable rights are different within the three treaties, with only the right to life, the ban on torture and cruel, inhuman, or degrading treatment, the prohibition of slavery, and the non-retroactivity of criminal charges being mentioned in all three treaties. ${ }^{35}$ When trying to identify "essential rights" within the global human rights canon, these four rights will have to be considered with particular care.

Article 4(1) and Article 4(2) ICCPR are interesting insofar as they offer one particular understanding of the notion of essence. Essence here means that a right in its entirety is considered essential for the realization of civil and political rights. These listed rights are absolute and inviolable as a whole, and no restriction can ever be permitted. ${ }^{36}$ Some rights are thus per se of such paramount importance for the promotion of civil and political rights in general that they cannot be derogated from, not even in extreme circuümstances like the asserted purpose of preserving the

\footnotetext{
${ }^{31}$ These are the rights to life, no torture, cruel or inhuman treatment, no slavery, no servitude, no imprisoned on the ground of inability to fulfil a contractual obligation. No one shall be held guilty of any criminal offence on account of any act or omission which did not constitute a criminal offence, under national or international law, at the time when it was committed. Nor shall a heavier penalty be imposed than the one that was applicable at the time when the criminal offence was committed, right to recognition everywhere as a person before the law, right of freedom of thought etc. International Covenant on Civil and Political Rights, Dec. 16, 1966, S. Treaty Doc. No. 95-20, 6 I.L.M. 368 (1967), 999 U.N.T.S. 171 [hereinafter ICCPR].

${ }^{32}$ The foregoing provision does not authorize any suspension of the following articles: Article 3 (Right to Juridical Personality), Article 4 (Right to Life), Article 5 (Right to Humane Treatment), Article 6 (Freedom from Slavery), Article 9 (Freedom from Ex Post Facto Laws), Article 12 (Freedom of Conscience and Religion), Article 17 (Rights of the Family), Article 18 (Right to a Name), Article 19 (Rights of the Child), Article 20 (Right to Nationality), and Article 23 (Right to Participate in Government). It also does not authorize the suspension of the judicial guarantees essential for the protection of such rights. American Convention on Human Rights, Nov. 21, 1969, 1144 U.N.T.S. 143 [hereinafter ACHR].

${ }^{33}$ No derogation from Article 2 (the right to life), except in respect of deaths resulting from lawful acts of war, or from Article 3 (prohibition of torture), Article 4 paragraph 1 (prohibition of slavery and servitude), and Article 7 (no punishment without law) shall be made under this provision. Convention for the Protection of Human Rights and Fundamental Freedoms, Nov. 4, 1950, Europ.T.S. No. 5; 213 U.N.T.S. 221 [hereinafter ECHR].

${ }^{34}$ U.N. Human Rights Committee (HRC), CCPR General Comment No. 29, Derogations during a State of Emergency, para. 13, U.N. Doc. CCPR/C/21/Rev.1/Add.11 (Aug. 31, 2001). See also Clementine Olivier, Revisiting General Comment No. 29 of the United Nations Human Rights Committee: About Fair Trial Rights and Derogations in Times of Public Emergency, 17 LEIDEN INT'L L.J. 405, 405-19 (2004).

${ }^{35}$ In particular, Article 27 ACHR declares the freedom of conscience and religion non-derogable, whereas a similar provision is lacking in the other treaties.

${ }^{36}$ This is the similar to the conceptualization of "absolute breach of essence" that Brkan suggests for EU law. See Brkan, supra note 2 , at 358 .
} 
life of the nation ${ }^{37}$-an exception that has to be applied restrictively anyway. ${ }^{38}$ These rights must be understood as a very limited number of core human rights, exempt from the consensus principle $^{39}$ of international law. For these rights, their scope and their essence are identical. At the macro level of international human rights law, the rights identified in Article 4(2) ICCPR constitute the "essence" of the whole field of civil and political rights.

An interesting related question is whether such essential, or absolute, rights, as listed in Article 4(2) ICCPR, also rank higher in terms of the hierarchy of potentially conflicting rights. ${ }^{40}$ In this way, they could be seen as being part of ius cogens ${ }^{41}$ as described in Article 53(2) Vienna Convention on the Law of Treaties as "a peremptory norm of general international law ... accepted and recognized by the international community of States as a whole as a norm from which no derogation is permitted and which can be modified only by a subsequent norm of general international law having the same character." At a minimum, the identified non-derogable norms - the right to life, the ban on torture, the prohibition of slavery, and the non-retroactivity of criminal charges-are widely considered to have the status of ius cogens in international law. ${ }^{42}$

\section{Article 5 ICCPR}

Another approach to the idea of an "essence" of international human rights is not to identify essential human rights, but to identify an essential part within a human right. Such an approach is expressed, albeit indirectly, in Article 5(1) ICCPR which states that

[n]othing in the present Covenant may be interpreted as implying for any State, group or person any right to engage in any activity or perform any act aimed at the destruction of any of the rights and freedoms recognized herein or at their limitation to a greater extent than is provided for in the present Covenant. ${ }^{43}$

Article 5(1) ICCPR thus suggests that there is an inviolable part within human rights and that this core may never be destroyed. In this way, civil political rights hold a sacrosanct core.

Without more being said in Articles 4 and 5 ICCPR, these ideas of core remain very abstract and are hardly tangible for others, such as practitioners. The "Siracusa Principles on the Limitation and Derogation of Provisions in the International Covenant on Civil and Political Rights," 44 in which thirty-one experts in international law interpreted Articles 4 and 5 of the ICCPR at a conference in Siracusa, Italy, in 1984, must be considered until today as the leading approach to understanding these provisions of the ICCPR. Therein, the participants examined the limitation and derogation provisions of the ICCPR, identifying legitimate objectives, general principles of interpretation, and some of the main features of the grounds for limitation or derogation within the ICCPR.

\footnotetext{
${ }^{37}$ U.N. Commission on Human Rights, The Siracusa Principles on the Limitation and Derogation Provisions in the International Covenant on Civil and Political Rights, para. 58, U.N. Doc. E/CN.4/1985/4 (Sept. 28, 1984) [hereinafter Siracusa Principles].

${ }^{38} I$ d. para. 61.

${ }^{39}$ The consensus principle states that international law derives only from the consensus of States and restrictions to State sovereignty may therefore not easily be presumed. See case concerning the S.S. Lotus (Fr. v. Turk), Judgment, 1927 P.C.I.J. (ser. A) No. 10, 18 (Sept. 7).

${ }^{40}$ See for a good overview, Teraya Koji, Emerging Hierarchy in International Human Rights and Beyond: From the Perspective of Non-Derogable Rights, 12 Euro. INT'L L.J. 917, 917-41 (2001).

${ }^{41}$ Different, but related is the question to whom the protection of these rights is owed other than the protected individuals; arguably, the owed obligations could be understood as "erga omnes" or at least "erga omnes partes" obligations.

${ }^{42}$ Cf. Christian Tomuschat, Human Rights 44-45 (2014); Antonio Cassese, A Plea for a Global Community Grounded in a Core of Human Rights, in ReAlizing Utopia, 136, 139 (Antonio Cassese ed., Oxford Univ. Press 2012).

${ }^{43}$ Italics added.

${ }^{44}$ Siracusa Principles.
} 
While the ICCPR itself does not use the term "essence" in Articles 4 and 5 ICCPR, the experts' interpretative guidelines refer exactly to this language. The experts state that "[t]he scope of a limitation referred to in the Covenant shall not be interpreted so as to jeopardize the essence of the right concerned." 45 Unfortunately, such essence is not further defined in the Siracusa Principles, nor is it clear whether the above stated assumption stems rather from Article 4 or Article 5 ICCPR, or a combination thereof. It seems most appropriate to assume the "essence" mentioned here to be derived from Article 5(1) ICCPR, given that "limitations" represents the language of this Article.

In further interpreting the possibility of restrictions under the ICCPR, the UN Human Rights Committee (UNHRC) in its General Comment No. 27 on the freedom of movement within Article 12 ICCPR noted that "adopting laws providing for restrictions permitted by article 12, paragraph 3, States should always be guided by the principle that the restrictions must not impair the essence of the right ${ }^{46}$; the relation between right and restriction, between norm and exception, must not be reversed." ${ }^{27}$ The UNHRC here makes clear that it speaks to the essence within each individual right and therefore connects the notion of essence to Article 5(1) ICCPR. While the experts explicitly only speak about Article 12 ICCPR here, due to the focus of the General Comment, it would appear very likely that the Committee would apply the same logic to other civil and political rights. The second half of the sentence adds that the relation of rule- the guaranteed right - and exception - the permissible limitation - may not be reversed. It is not clear whether the Siracusa experts thought this assertion as part of the "essence" idea, or rather as a self-standing second restriction on possible human rights limitations. On the one hand, the non-reversibility idea could be seen as part of the notion of essence: Both are mentioned in the same paragraph of the General Comment, without any pause or hesitation and only separated by a mere semicolon. On the other hand, there is no indication that the experts wanted to establish a comprehensive definition of a right's essence here by introducing the idea that rule and exception may never be reversed. Rather, they pointed out one particular pertinent case constellation in which the essence of a right would typically be violated: When the rule protecting the right becomes the exception limiting the right and vice versa. Similarly, in General Comment No. 31 on the "nature of the general legal obligations imposed on States Parties to the Covenant," the UNHRC stated that "in no case may ... restrictions be applied in a manner that would impair the essence of a Covenant right." 48

In 2004, in his report A/69/397, the Special Rapporteur on the promotion and protection of human rights and fundamental freedoms while countering terrorism stated that "assuming ... that there remains a legal right to respect for the privacy of digital communications ... the adoption of mass surveillance technology undoubtedly impinges on the very essence of that right," and that "the essence of the right to privacy of communication is that infringements must be exceptional, and [must be] justified on a case by case basis." 49 The Special Rapporteur also states that "there are limits to the extent of permissible interference with a Covenant right. As the Human Rights Committee has emphasized, 'in no case may the restrictions be applied or invoked in a manner that would impair the essence of a Covenant right." 50 In the context of covert surveillance, the Committee has therefore stressed that any decision to allow interference

\footnotetext{
${ }^{45} I d$. at $\mathrm{I}(\mathrm{A})(2)$.

${ }^{46}$ The Committee here refers explicitly to Article 5, paragraph 1 ICCPR (although the wording of 'essence' is not used in Art. 5 ICCPR explicitly).

${ }^{47}$ U.N. Human Rights Committee (HRC), CCPR General Comment No. 27, Freedom of Movement, para. 13, U.N. Doc. CCPR/C/21/Rev.1/Add.9 (Nov. 2, 1999).

${ }^{48}$ General Comment No. 31, supra note 18 , at para. 6.

${ }^{49}$ Ben Emmerson (Special Rapporteur), Rep. on the Promotion and protection of human rights and fundamental freedoms while countering terrorism, para. 18, U.N. Doc. A/69/397 (Sept. 23, 2014).

${ }^{50} I d$. at para. 51 .
} 
with communications must be taken by the authority designated by law "on a case-by-case basis." 51 The Special Rapporteur concludes that

[b]ulk access technology is indiscriminately corrosive of online privacy and impinges on the very essence of the right guaranteed by article 17. In the absence of a formal derogation from States' obligations under the Covenant, these programs pose a direct and ongoing challenge to an established norm of international law." ${ }^{52}$

These observations by the Special Rapporteur are enlightening in several ways. First, as in the European example of Schrems, it was a case of modern technology relating to data collection that triggered the question of the essence of rights. These constellations seem to be typical cases in which the question of essence may be invoked. The reasons might be first, that here the ruleexception-constellation is typically reversed, particularly in the case of mass surveillance programs. Data is in a first step monitored and collected, and only in a second step is the decision about sensitive individual data made. In cases of mass surveillance, "interference" with the right to privacy is thus the rule while it should be the exception. Second, without being notified, the individual is not even aware that an infringement happens-so any chance to react or redress the issue is cut off $a b$ initio, and in this way there is nothing left of the right. ${ }^{53}$ It will be interesting to see how the jurisprudence in cases of mass surveillance will develop and what action exactly will be qualified as the interference of the essence, either already the initial collection of the data which would be a rather far reaching approach or the access to it which seems to be the Special Rapporteur's approach when stating that generalized access to data-rather than its initial aggregation-is infringing the essence of right to privacy.

Second, the question arises from the Special Rapporteur's reports of whether the "very essence," as referred to in some of his statement, is to be understood differently from "the essence." I suggest, however, to equate these terms. If we understand the essence of human rights already in absolute terms, there is no room-and no need-for further distinction. What would it mean for a violation to concern the "very essence" of a right, rather than only "the essence"? The use of the term "very essence" by the Special Rapporteur should thus be understood as a mere affirmative rhetorical means and not as an attempt to introduce yet another category-of a core of a core, and so on.

Finally, in Yoon and Choi v. the Republic of Korea, ${ }^{54}$ the Human Rights Committee had to consider a communication brought forward by two Korean nationals, both Jehovah's witnesses, who had refused to serve their military service in the Korean army and were sentenced to imprisonment as a consequence. They claimed a violation of their rights under Article 18 ICCPRfreedom of thought, conscience, and religion. In considering the imprisonment indeed a violation, the HRC argued again that any restriction on Article 18 ICCPR "must not impair the very essence of the right in question." 55 Directly following this paragraph, the Committee performs a proportionality analysis.

The approach here is not clear and allows for two different interpretations. In a first possible interpretation, while the general understanding of essence in international law is that an essence

\footnotetext{
${ }^{51} I d$. at para. 51 (referring back to U.N. Human Rights Committee (HRC), CCPR General Comment No. 16, The Right to Respect of Privacy, Family, Home and Correspondence, and Protection of Honour and Reputation, para. 8, U.N. Doc. A/HRC/ 27/37 (Apr. 8. 1988)).

${ }^{52} I d$. at para. 59.

${ }^{53}$ Arguably, however, this could then be seen as a violation of different judicial rights rather than the right to privacy. Schrems found violations of the essence of both rights—right to privacy and right to effective judicial protection. For a convincing critique why only the latter should have been found to be violated in its essence, see Brkan, supra note 2, at 360-61.

${ }^{54}$ U.N. Human Rights Committee (HRC), Yeo-Bum Yoon and Myung-Jin Choi v. Republic of Korea, U.N. Doc. CCPR/C/88/ D/1321-1322/2004 (Jan. 23, 2007).

${ }^{55}$ Id. at para. $8(3)$.
} 
breach leads to an unjustifiable violation- "absolute theory" of essence ${ }^{56}$ —we might witness here the opposite approach: A relative $e^{57}$ understanding of what follows from an essence breach. After having raised the issue of essence, the experts go on to conduct a proportionality test. In that analysis, the experts criticize that no milder alternatives were employed, making mandatory military service without alternatives a non-necessary measure under Article 18 ICCPR. ${ }^{58}$ If taking the absolute understanding of essence, the relationship between essence and proportionality would be a different one-one of mutual exclusivity. Where the essence of a right is at stake, there is no room for a proportionality analysis. No restriction, be it proportional or not, is allowed if the essence is concerned. In turn, if judges, or quasi-judges, perform a proportionality analysis, it might mean that they took a different approach to essence-namely a "relative" understanding. In this case, the threshold for justifying an essence breach is heightened, but a breach of relative essence can in theory be justified. Then a particularly strict proportionality analysis must be conducted.

There is, however, also a second understanding of Yoon and Choi v. Republic of Korea. The quoted sentence about the essence does not say anything about the particular case. It might also be a mere general reminder that the notion of essence of human rights exists but is not at stake in the case at hand. In this reading of the opinion, the Human Rights Committee would not propose a relative essence understanding; it would equally not suggest that an infringement of the essence can be justified if it is proportionate. In this reading, the committee would merely state-quasi as an obiter dictum not relevant to the case-that an interference touching upon the essence of Article 18 ICCPR can never be justified, but given that the essence is not at stake in the case at hand, the committee proceeds with a proportionality analysis.

Given this decisive ambiguity, the case of Yoon and Choi v. Republic of Korea should not be overrated when developing an understanding of essence in international human rights law.

\section{Conclusion for Civil Political Rights}

Taking these different approaches together, the idea of essence of civil political rights can be found at the macro and at the micro levels of international law. At the macro level, Article 4(1) and 4(2) ICCPR identify a small number of rights that are essential for the realization of civil and political rights altogether. They are in their entirety sacrosanct. At the micro level, Article 5(1) ICCPR forbids any act to be aimed at the destruction of civil political rights. It thereby establishes a core within each civil political right. The practical effect of infringing the essence within a right is not entirely clear. Most interpretations have taken the view that such essence may not be restrictedthereby taking an "absolute" understanding of such a core, where there is no room for any attempts of justification, such as a proportionality analysis. Only individual decisions-like Choi and Yoon v. Korea-point to a relative understanding of the core. We have also seen that while certain case constellations trigger the essence under Article 5(1) ICCPR more frequently-such as the right to privacy being challenged in cases of mass surveillance - the notion generally applies to all ICCPR rights.

\section{The Notion of "Essence" in Economic, Social, and Cultural Rights}

The concept of essence is very different in the context of economic, social, and cultural rights. States are obliged, according to Article 2(1) ICESCR, to "tak[e] steps to the maximum of their available resources, with a view to achieving progressively the full realization of the rights of

\footnotetext{
${ }^{56}$ Such an understanding is mirrored for instance in the case of the German, the Spanish and the legal understanding of essence. See Brkan, supra note 2, at 341 (Brkan also suggests an absolute theory for the notion of essence in EU law), as well as Koen Lenaerts, Limits on Limitations: The Essence of Fundamental Rights in the EU, 20 GERMAN L.J. 779 (2019).

${ }^{57}$ As is, for instance, the predominant approach in the legal systems of Austria and Hungary. See Brkan, supra note 2, at $342-43$

${ }^{58}$ Yeo-Bum Yoon, supra note 54, at para. 8(4).
} 
the Covenant." The obligations under the ICESCR are thus resource-dependent and progressive in nature, which seriously hinders their justiciability in practice.

\section{Article 4(1) ICESCR}

Article 4 ICESCR specifies that "only ... such limitations as are determined by law only insofar as this may be compatible with the nature of these rights and solely for the purpose of promoting the general welfare in a democratic society." While the wording in Article 4 ICESCR does not speak to the "essence" of rights, the obligation not to violate the "nature" of rights must be understood as being very similar to protecting their essence.

Similar to the Siracusa Principles for Civil and Political Rights, the 1986 Limburg Principles ${ }^{59}$ are an elaboration by experts to specify the implementation of the rights under the ICESCR. In these principles, the experts state what, in their view, is meant by the phrase "compatible with the nature of these rights," namely "a limitation of these rights shall not be interpreted or applied so as to jeopardize the essence of the right concerned." 60 The notion "compatible with the nature" of socioeconomic rights thus introduces and emphasizes a non-restrictable component of ICESCR rights in order to rule out extreme restrictions. ${ }^{61}$ In this way, the notion employed here is a mirror of Article 5(1) ICCPR for socioeconomic rights and reflects the analysis already discussed in respect of Article 5(1) ICCPR.

In the case law of the ESCR Committee, the notion of "compatible with the nature" of socioeconomic rights has not become relevant yet, which might be for two reasons. First, the individual complaint procedure under the ICESCR only entered into force in 2013 and has only seen few cases. In the future, we may well see cases invoking the protection of the nature of rights. Second, the focus of challenging socioeconomic rights often lies on the lack of state action-where a State has not acted to fulfil its duty - not so much on state action-where a State through its action itself has violated a right. Violations that a State has created itself might be seen as more incompatible with the nature of the rights the State has promised to uphold in comparison to cases where the State has just not acted sufficiently to develop these rights over time. Therefore, the notion of essence previously identified in the context of civil and political rights might be less relevant for the majority of cases where socioeconomic rights are at stake.

\section{The Concept of Minimum Core of Socioeconomic Rights}

There is, however, another, more relevant, aspect of essence relating to socioeconomic rights. Given that their realization is progressive and resource-dependent according to Article 2 ICESCR, from the beginning, the experts in the ESCR Committee were concerned about the rights' lack of realization and their weak justiciability. In General Comment No. $3^{62}$ from 1990, the experts introduced the idea of a "minimum core" of socioeconomic rights. Therein the experts stated that:

\footnotetext{
${ }^{59}$ U.N. Human Rights Committee, Note verbale dated 5 December 1986 from the Permanent Mission of the Netherlands to the United Nations Office at Geneva addressed to the Centre for Human Rights ("Limburg Principles"), Annex, U.N. Doc. E/ CN.4/1987/17 (Jan. 8, 1987).

${ }^{60} \mathrm{Id}$. at para. 56.

${ }^{61}$ Ben SAul et al., The International Covenant on Economic, Social and Cultural Rights, Commentary, Cases, AND MATERIAL 237 (2014). The authors use the word "non-derogability," but in the terminology used in this Article, nonrestrictability is the more appropriate term.

${ }^{62}$ U.N. Committee on Economic, Social and Cultural Rights (CESCR), General Comment No. 3, The Nature of States Parties' Obligations (Art. 2, Para. 1, of the Covenant), para. 10, U.N. Doc. E/1991/23 (Dec. 14, 1990). See also Danilo Türk, Special Rapporteur on Problems, Policies and Progressive Measures relating to a More Effective Realization of Economic, Social and Cultural Rights, Second Progress Rep. on the Realization of Economic, Social and Cultural Rights, para. 52(d), U.N. Doc. E/CN.4/Sub.2/1991/17 (July 18, 1990).
} 
[A] minimum core obligation to ensure the satisfaction of, at the very least, minimum essential levels of each of the rights is incumbent upon every State party. [A] State party in which any significant number of individuals is deprived of essential foodstuffs, of essential primary health care, of basic shelter and housing, or of the most basic forms of education is, prima facie, failing to discharge its obligations under the Covenant. If the Covenant were to be read in such a way as not to establish such a minimum core obligation, it would be largely deprived of its raison d'être. ${ }^{63}$

General Comments, while not creating new legal obligations, are authoritative interpretations of the Covenants and have to be considered with particular care when understandings the different Covenant rights. ${ }^{64}$ While the obligations under the Covenant are generally progressive and resource-dependent with only few exceptions laid down, ${ }^{65}$ the Committee here establishes another immediate and resource-independent obligation for which there is not a direct counterpart in the articles of the ICESCR. The experts here rather employ an interpretation of Article 2 ICCPR along the lines of the customary law rule of "object and purpose" interpretation, ${ }^{66}$ as becomes very clear from their "raison d'etre" argument.

What the experts did, de facto, was to exempt this part of the rights from the limitations that the wording of Article 2 ICESCR poses: First, the realization of the minimum core is demanded by States immediately and independently of resources. While less directly hinted at in General Comment No. 3, the experts thereby address the most pressing problem that socioeconomic rights regularly face: Their disputed justiciability. Especially in the Anglo-American tradition, it has often been claimed that socioeconomic rights cannot be enforced by courts for a variety of reasons: They were allegedly never meant to be rights but policy goals; they are claimed to be too expensive to be enforced as rights, particularly for developing States; when interpreting them, judges should not impose obligations on the democratically elected legislature and the executive and should honor the separation of power; and altogether, socioeconomic rights were formulated too broadly to be enforceable by courts in the first place. At least for the minimum core, the Committee wanted to rule out such arguments. By establishing an essence in the form of a minimum core, the Committee thus wanted to strengthen the backbone of socioeconomic rights and identify a specific part of these rights to which the well-known weaknesses of second generation rights, as laid down in Article 2 ICESCR, would not apply.

\section{E. The Four Different Essence Approaches in International Human Rights Law}

Reading these findings together and comparing them, we find four partly overlapping approaches to essence of international human rights.

In the case of civil political rights, the concept has two flavors. First, under Article 4(2) ICCPR, certain rights are declared sacrosanct. If they are at stake, no justification under the ICCPR is possible. At the macro level of the canon of all civil and political rights, there are a number of essential rights that enjoy special protection. Thus, in this way, the concept of essence can apply to civil and political rights as a whole. This concept of essence is not mirrored in the ICESCR; it does not apply to socioeconomic rights.

\footnotetext{
${ }^{63}$ U.N. Committee on Economic, Social and Cultural Rights (CESCR), General Comment No. 3, The Nature of States Parties' Obligations (Art. 2, Para. 1, of the Covenant), para. 10, U.N. Doc. E/1991/23 (Dec. 14, 1990).

${ }^{64} \mathrm{Cf}$. Ahmadou Sadio Diallo (Rep. of Guinea v. Dem. Rep. Congo), Judgment, 2010 I.C.J. Rep. 103, g 66 (Nov. 30).

${ }^{65}$ These are commonly considered to be "to take [at least some] steps" and doing so in a manner that is non-discriminatory. See International Covenant on Economic, Social and Cultural Rights arts. 2(1), 2(2), Jan. 3, 1976, 993 U.N.T.S. 3 [hereinafter ICESCR]. See also SAUL, supra note 61, at 137.

${ }^{66}$ This interpretation is mirrored in Art. 31(1) VCLT which, however, does not apply retroactively to the Covenant. Vienna Convention on the Law of Treaties art. 31(1), opened for signature May 23, 1969, 1155 U.N.T.S. 331. [hereinafter VCLT].
} 
Second, under Article 5 ICCPR, the essence consists of a core of the right in question with which the signatory States of the ICCPR can under no circumstances interfere. Interference with the right cannot be justified by any reasons offered by the State as an explanation. An "infringement of the essence" thus equals the "violation of the right." There is no room for a proportionality analysis - at least if one understood this essence in an absolute way, as the majority of interpretations of Article 5 ICCPR suggest. In this way, the concept of "essence" can also apply to individual civil political rights and protect their most important, indispensable element.

Turning to socioeconomic rights, there is no comparable essence concept that would apply to rights in their entirety, like in Article 4 ICCPR. The obligation, however, under Article 4 ICESCR - not to engage in action against the nature of socioeconomic rights- has been understood as a protection of the rights' essence, in particular in the interpretation of the Limburg Principles. This third concept of essence seems to be almost, if not entirely, identical to that of Article 5 ICCPR. It has in the practice of the protection of socioeconomic rights, however, not yet become relevant. Much more important in the practice of socioeconomic rights has been a fourth flavor of essence: The notion of a minimum core. The minimum core notion identifies obligations that are immediately and resource-independently owed; as a result, they are meant to be more justiciable for individuals before national courts or the new Individual Complaint Procedure that the Covenant has had in place since 2013 following its Optional Protocol.

When taking these approaches together, we can identify three main features of the concept of essence in international human rights law. One of these applies explicitly to civil political rights— "non-derogability" — one applies to both sets of human rights - "non-restrictability" and one applies only to socioeconomic rights- "justiciability of a minimum core." Depending on the individual case constellation, one or several of these elements of essence may be at stake.

First, essence can mean "non-derogability." States are prohibited to derogate from the most essential of civil political rights, even in situations of extraordinary public emergencies. "Essence" in this way is a shield against exceptionalism; the most important of human rights must always be upheld. The entire scope of these rights is "essential."

Second, "essence" can also be understood as non-restrictability. While recognizing that human rights remain generally applicable, the State can restrict human rights in order to protect a contradicting public value, such as public security or the rights of others. Generally, such a restriction must fulfill the requirements of a proportionality analysis. In contrast, essence means that a certain core of a right cannot be restricted-not even when promoting a conflicting public aim in a suitable and necessary manner. Such a core of a right cannot be infringed upon-whatever the State's justification may be. This element holds true for both sets of international human rightsalthough it has become much more relevant in practice for civil political rights.

Thirdly, when looking at socioeconomic rights, the focus shifts to "justiciability." Under the concept of minimum core, the "essence" is an umbrella term for obligations different from the ones generally owed under Article 2 ICESCR: The essence here identifies immediate and resource-independent State obligations. While States have great discretion in terms of the realization of socioeconomic rights, this does not hold for their minimum core. To realize at least the bare minimum of the right to health or education is an immediate obligation under the "minimum core," independent of available resources. Immediacy and resource independency are key to increasing the often-bemoaned limited justiciability of socioeconomic rights, and "essence" has been developed as tool to address this deficiency.

\section{F. Conclusion: The Concept of "Essence" in International Human Rights Law-A Model for European Law?}

In this Article, I have identified two distinct characteristics of the notion of essence in international human rights law. First, we have seen that "essence" has very different features in international law depending on what generation of human rights is at stake. For civil political 
rights, "essence" relates mainly to the question of which rights a State can derogate from in times of extreme emergencies, and, even if a right in general is derogable, what inner part of rights can never be subject to restriction. For socioeconomic rights, while the concept of non-restrictability in general applies, the main question is which parts of socioeconomic rights are lifted beyond the severe limitations of progressive realization and resource availability, to make socioeconomic rights justiciable in practice.

Second, the concept of essence applies to different levels within international human rights law. At the macro level, it establishes within the canon of human rights some rights of paramount importance. At the micro level, it allows us to identify a core within a given human right that is sacrosanct. At the level of realization, "essence" in the form of minimum core makes it impossible for States to excuse themselves with regard to non-immediacy or resource-dependency in terms of their owed obligations.

Having understood these two characteristics of the notion of essence in international human rights law, two related questions remain that have also been asked for European law following Schrems. First, can rights in their entirety be "essential"? And second, in the logical opposite, can rights in their entirety be non-essential?

The first question is rather straightforward to answer. As I have shown in light of Article 4(2) ICCPR and given the fact that the concept of ius cogens is well established in international law-to an even greater extent than absolute rights are accepted in EU law-the answer is clearly positive. Just as some rights have a core that is their essence, some other rights' entire scope is their essence. An infringement on these specific rights - of which there are very few-cannot be justified, either by the means of a proportionality analysis or in any other way. ${ }^{67}$

The second issue is harder to answer: Do all rights have an essence-be it their core or their entire scope? For EU law, this question has not been answered convincingly, with some authors just stating this to be the case without further examination. ${ }^{68}$ For international human rights, the identified sources have not provided certainty either. I have argued that socioeconomic rights should not generally be excluded from having an "essence," emphasizing their importance for the individual and their interrelatedness with civil political rights. This, however, should not lead us to the opposite conclusion: That every right necessarily has an essence. In some legal traditions, such as the aforementioned German one which certainly influenced the EU Charter of Fundamental Rights significantly, the essence is frequently related to the notion of human dignity, as is clearly the case for the German Grundgeset $z^{69}$. This, however, should not easily be assumed for international law, where much more diverse legal traditions come together than in EU law, and where the notion of human dignity following the German model has less influence than in EU law. In particular with regard to some particularly contested socioeconomic rights, it is well imaginable that the majority of States may consider them parts of the human rights canon, without believing them to have an untouchable essence. If we included the even more contested third generation of human rights into our analysis-group rights such as the right to development or the right to self-

\footnotetext{
${ }^{67}$ An interesting argument, albeit going beyond the scope of this Article, concerns the question whether the understanding of essence differs dependent on whether a state of emergency has been declared or not under Article 4 ICCPR. If Article 18(1) ICCPR, for instance, can be restricted in "normal times" according to Article 18(3) ICCPR, shouldn't this possibility of restrictability hold even more for times of emergency? Otherwise, a person would enjoy more protection under Article 18(1) ICCPR in times of emergency than she would in non-emergency times. This would in turn mean that the declaration of emergency would make it harder for States to curtail human rights while the purpose of the declaration is to make it easier for them. Thus, an interesting question for future research is the relationship between Article 4 ICCPR and Article 5 ICCPRis the level of essence under Article 5 ICCPR influenced by the declaration of an emergency, or not?

${ }^{68} \mathrm{Brkan}$, for instance, admits that the claim that each (emphasis added) fundamental right has an inalienable essence has not yet been empirically proven, but follows from Brkan from "argumentative logic." Brkan, supra note 2. Admittedly, the EU Charter of Fundamental Rights and Freedoms itself gives the impression that all fundamental rights have an essence given its wording in Art. 52(1), although this wording is not unambiguous.

${ }^{69}$ Article 19(2) German Grundgesetz in connection with Article 1 German Grundgesetz.
} 
determination - the case that all human rights necessarily have an untouchable essence becomes even harder to make.

Having now understood the different notions and applications of essence in international human rights law, a last question arises: To what extent the international law analysis can guide the further development of the EU Charter concept? What, if anything, is there to be learned from the experience of international law with the essence of human rights? I would like to offer three observations.

First, while national legal traditions and the case law of the ECtHR have been widely considered when understanding the ECJ's concept of essence, general international law has so far been largely overlooked. The concept of essence, however, has been featured in general international law for a long time-arguably because levels of protection on a global scale and the senses of how much limitation to a right might be justified are far more divergent than within the EU, so that there is more need for establishing an untouchable essence. The first lesson from international law then is that there is not necessarily one gold standard when determining a notion of essence. As we have learned from international law, the notion of essence can establish a ranking between an existing canon of human rights- "non-derogability"-identify a core within a right that cannot be infringed upon-"non-restrictability" - or make otherwise weak obligations enforceable"justiciability." Which of these aspects is most relevant depends on which right is at stake, with the distinction between civil political or socioeconomic rights being of utmost importance. As European law encompasses both generations of fundamental rights, even if less explicitly so, more than one concept of essence might also be of relevance for EU law. Given the smaller differences in the legal orders and the economic conditions of EU states vis-à-vis the global community of States, some elements of the "essence" concept identified might be of greater importance within the EU context—such as establishing non-restrictability-or of lesser importance-such as increasing justiciability. At the very least, there are good reasons why EU law should take international law into account. First, for the specific case of the European Convention for the Protection of Human Rights and Fundamental Freedoms (ECHR) and its inclusion into EU law according to Article 6(2) TEU. Second, EU law-like the law of its Member States-has traditionally been described as open, rather than closed, to public international law. ${ }^{70}$ Some even understand EU law to be part of international law. ${ }^{71}$ Third, the Member States are signatories to the two Covenants. Convergence between EU and International Human rights law is thus desirable. From the perspective of international law, this follows also from Article 31(3)(c) VCLT, which states that when interpreting one treaty any other relevant rules of international law applicable in the relations between the parties should be used as means of interpretation.

Moving on to a second observation, adopting parts of the approach of international law when applying the concept of essence means to categorize human or fundamental rights as being either civil political or socioeconomic. This is inter alia so that several elements of essence only apply to one or the other of the two sets of human rights. This dichotomy of the international human rights system has been criticized extensively in the literature. It has arguably done much harm to socioeconomic rights, which are until today often understood as the less important of the two sets of rights. If following the different concepts of essence also in European fundamental rights law, it might equally mean deepening the divide between civil political and socioeconomic rights within EU law-where such distinctions appear thus far less strict, as the distinction rather runs

\footnotetext{
${ }^{70}$ Just to give one example, the German principle of "Völkerrechtsfreundlichkeit des Grundgesetzes" is well established in the case law of the Bundesverfassungsgericht.

${ }^{71}$ For example, the EU has been called an "international organization in the framework of the applicable international legal system” by Oliver Dörr, EUV Art. 47, in Eberhard Grabitz, Meinhard Hilf and Martin Nettesheim (Eds.), Das Recht der Europäischen Union, 66. Ergänzungslieferung February 2019, available through Beck Online, point 11 (author's own translation).
} 
along the lines of enforceable rights and less enforceable principles. ${ }^{72}$ Thus, applying the different notions of essence found in international law might needlessly force EU law to adopt unwanted or even weakening features of international law, such as the strict separation between first and second generation rights. In this way, some rights, which in the international legal plane are considered socioeconomic rights, might be weakened in the EU legal system where they have so far enjoyed a stronger legal status, such as the right to strike, including the accepted direct effect attached to it. Under international law, this would be considered a difficult to enforce and relatively nonjusticiable socioeconomic right. ${ }^{73}$ Thus, while the analysis has shown that the EU legal order should learn from international law with regard to "essence," it should do so with caution, and be aware of some of the problems that international law has also encountered with its approach to "essence."

Third, the establishment of the concept of essence in international human rights law by judges and quasi-judges was clearly driven, inter alia, by the lack of a legislator in international law. Where there is a legislator, this legislator can spell out clear and concrete minimum levels of protection. In the EU, there is a strong legislator that can determine what levels have to be guaranteed in primary and secondary EU law; levels that are then also enforced by the courts. In international law, establishing amendments or changes to Covenants is hard and time consuming, as we know for instance from the Optional Protocol to the ICESCR that took several decades to be accepted by States. Given the possibilities that the European legislator has which do not exist in international law, and given the much stronger enforceability of rights in EU law as compared with international law, there might in general be a lesser reason for EU judges to develop and employ a concept of essence in comparison to their colleagues applying international human rights law. This, of course, depends largely on the willingness of the EU legislature to use this power, such as to elaborate concrete legislation protecting the essence of rights. This may not be easy given the uneasy patchwork of competences afforded to the EU in the area of human rights protection which, at least for the time being, might suggest a continuing need for judicial elaboration of the concept of "essence."

\footnotetext{
${ }^{72}$ For this important distinction, see for instance-out of many — the ECJ's landmark decision in Case 176/12, Association de Médiation Sociale, 2014 E.C.R. (concerning the question of horizontal effect of the workers' right to information and consultation (Article 27 of the Charter of Fundamental Rights) as implemented in Directive 2002/14, establishing a framework for informing and consulting employees in the Union, Case-176/12, Association de Médiation Sociale, 2014 E.C.R.). For the opinion of the Advocate General of July 18, 2013, coming to a different conclusion, see Case C-176/12, Association de Médiation Sociale, 2013 E.C.R.

${ }^{73}$ See Case C-341/05, Laval un Partneri, Ltd. v. Svenska Byggnadsarbetareförbundet, 2007 E.C.R. I-11845; Case C-438/05, Int'l Transp. Workers' Fed'n v. Viking Line ABP, 2007 E.C.R. I-10806 (establishing right to strike in EU law).
} 